Szilvia Ormándi*, István Dódony

Eötvös Loránd University, Dept. of Mineralogy, Budapest, Hungary
Scientific paper

ISSN 0351-9465, E-ISSN 2466-2585

UDC:549.623.9:549.67

doi: $10.5937 /$ ZasMat 16045650

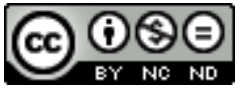

Zastita Materijala 57 (4)

565 - 570 (2016)

\title{
Synthesis and structural study of the Linde Type-A zeolite prepared from kaolinite
}

\begin{abstract}
The goal of this work is to synthesize and measure the crystal structuras of sodalite-related zeolites using X-ray power diffraction technique. We made a successful attempt to recover the Linde Type A (LTA) zeolite framework using $X$-ray diffraction data sets. Cation exchange was done in this structure with $\mathrm{Cs}^{+}$ions, in order to demonstrate the usability of LTA in the nuclear technique.

Linde Type A zeolite crystals were synthetized using $(\mathrm{NaOH})$ method from metakaolinite as the starting material. The resulted LTA crystals exhibit cubic and spherical shapes as showned by scanning electron microscopy.

In the LTA framework the interchangeable cations are $\mathrm{Na}^{+}$ions, which were replaced by $\left(\mathrm{H}_{3} \mathrm{O}\right)^{+}$ and $\mathrm{Cs}^{+}$ions respectively. We measured the resulted structural changes, using $X$-ray powder diffraction data in the SIR (Semi Invariant Reconstruction) program package.

The measured hkl and intensity data sets are the inputs for structure determination. Due to overlapping reflections, some samples resulted in high $R$-factor values. However, the resulted LTA-type framework proved to be evident. We refined the atom position in the SHELX program package.
\end{abstract}

Keywords: synthesis, zeolite, kaolinite, metakaolinite, LTA, ion exchange Cs, SIR.

\section{INTRODUCTION}

As usual, the main progress in the knowledge on zeolites was the successful structure determination. The first zeolite structure determination was carried out in 1929 by Professor Frans Maurits Jaeger [1]. Zeolites have complex alumosilicate frameworks. These frameworks are opened with large channels and interconnected cages. The structural channels and voids are occupied by loosely bounded cations and water molecules that we can remove and replace without disrupting the tetrahedral framework. This unique - so called, zeolitic - property provides a zeolite structure, the best candidate to perform cation exchange, adsorption, molecular sieving (passing a gas or liquid through a zeolite), dehydration and rehydration processes; in addition, it can be resistant to high energy radiation, too [2].

\footnotetext{
${ }^{*}$ Corresponding author: Szilvia Ormándi

E-mail: ormszi12@gmail.com

Paper received: 01. 11. 2016.

Paper accepted: 30. 11. 2016.

Paper is available on the website: www.idk.org.rs/journal
}

Thanks to these properties we use zeolites in oil and chemical industry. In 1948, when Barrer synthesized a new zeolite (later named ZK-5) with unknown natural counterpart, the industry started to dream about new frameworks having promising properties. The pioneer of this path was the Union Carbid's group, which has prepared Zeolite A, the new industrial absorbents, the Linde Type $A$ zeolite, used for the purification of argon [1].

However, we would like to emphasize the importance of zeolites in environmental protection, for example, nuclear waste treatment. This side of zeolites became known after Fukushima accident and many works investigate the efficiency of removing cesium using zeolite from radioactive liquid waste $[3,4]$. In this work we synthesized LTA zeolites to examine its $\mathrm{Cs}^{+}$form.

Ríos et al. [5] described two methods for LTA synthesis, the alkaline activated conventional hydrothermal, and the alkaline fusion prior to hydrothermal reaction. We used the latter one, where the added alkali reagent is an activator to mobilize framework forming $\mathrm{Al}$ and Si. The final products of the synthesis are the LTA with some 
cancrinite and sodalite as intermediate phases. Others had concluded that with alkali fusion method we do not need to purification the kaolin [6].

In recent research has examined how this kind of synthesis more efficient. For example using ultrasonic processing $(22 \mathrm{kHz})$, [7] or synthesis in continuous flow reactor [8].

Based on work [9] the factors determining the shape and size of the zeolites are aging time and crystallization temperature. According to latest research 600 or $650{ }^{\circ} \mathrm{C}$ of the required temperature, but there are new experiments of zeolite formation without external heating too $[10,11,12]$.

The LTA-type zeolite is built up from sodalite-, or $\beta$-cages, named as Periodic Building Unit. These units consisting of six 4-rings and four 6-rings and linked through double 4-rings, forming the LTA framework. The LTA zeolite structure contains other cages, the $\alpha$-cages. These cages with diameters of $7 \AA$ and $11 \AA$ can host different cations. The composition of the sodium LTA is $\mathrm{Na}_{12}\left(\mathrm{Al}_{12} \mathrm{Si}_{12} \mathrm{O}_{48}\right)_{27} \mathrm{H}_{2} \mathrm{O}$ and the space group is $\operatorname{Pm} \overline{3} \mathrm{~m} \quad(\mathrm{a}=12,3 \AA)$ or $\mathrm{Fm} \overline{3} \mathrm{c} \quad(\mathrm{a}=24,6 \AA) \quad$ [13].
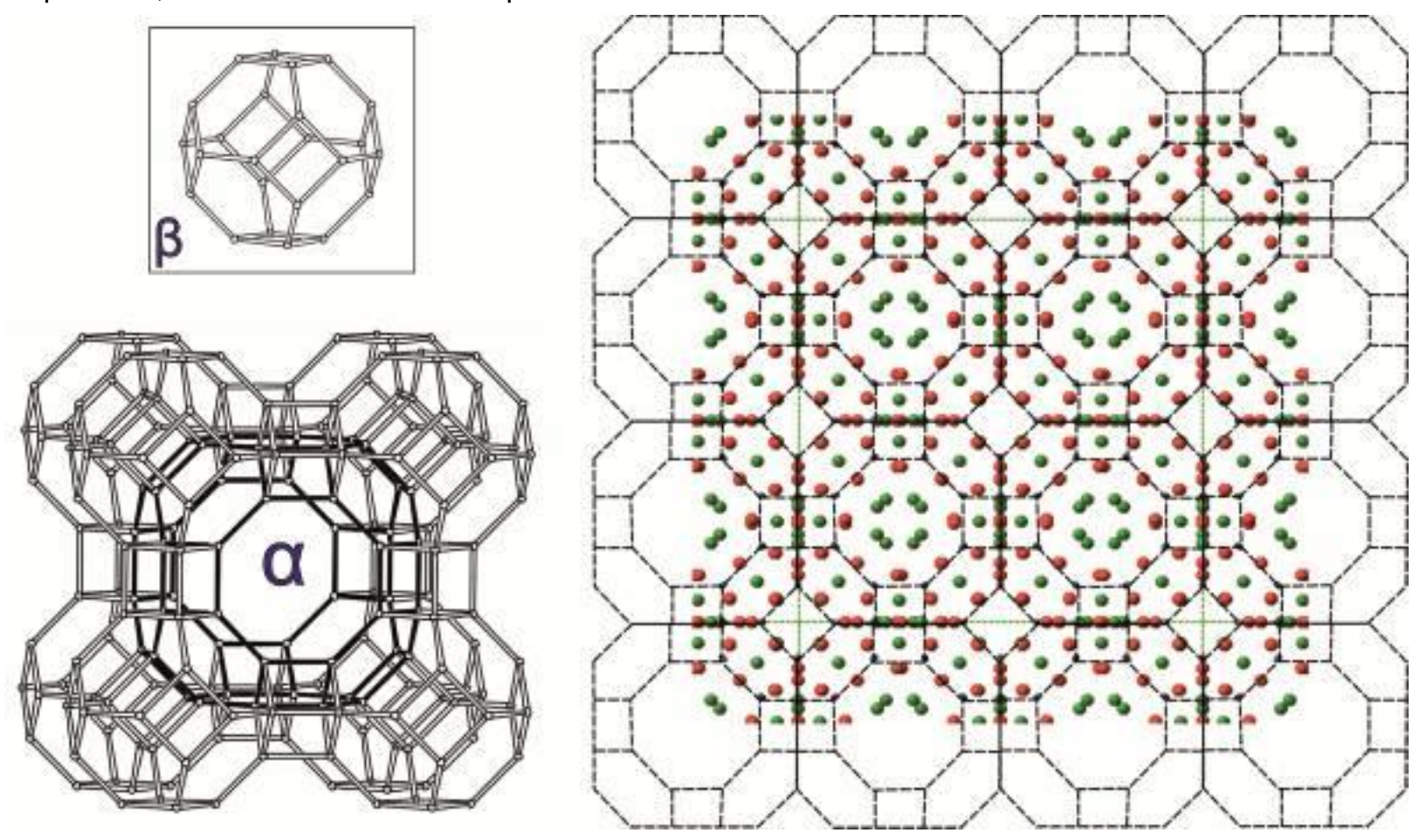

Figure 1 - The modell of sodalite-, or $\beta$-cage (upper left), and the a cage (lower left) named as Periodic Building Units [4] and the structure model of the Linde Type A (LTA) zeolite viewed down along the [100] [14].

\section{EXPERIMENTAL}

\subsection{Synthesis of LTA and its ion exchanged varieties}

We used commercial kaoline from Sedlec as starting material. It was heated up to $720^{\circ} \mathrm{C}$ to transform to metakaolinite, followed by alkaline $(\mathrm{NaOH})$ treatment at $80^{\circ} \mathrm{C}$ for 24 and 48 hours, respectively (Table 1 ). The $\mathrm{X}$-ray powder diffraction patterns of the washed and dried reaction products showed the characteristic reflections of the LTA zeolite phase. $\mathrm{Na}^{+}$ions were removed from the structural cages with hydrochloric acid, followed by $\mathrm{Cs}^{+}$ions saturation in suspension.
Table 1 - The conditions for LTA synthesis starting from metakaolinite

\begin{tabular}{|c|c|c|c|}
\hline & Time & $\mathrm{Na}(\mathrm{OH})$ & Sample/Solution \\
\hline 1. & $24 \mathrm{~h}$ & $3 \mathrm{~mol} / \mathrm{l}$ & $3 \mathrm{~g} / 17 \mathrm{ml}$ \\
\hline 2. & $48 \mathrm{~h}$ & $3 \mathrm{~mol} / \mathrm{l}$ & $3 \mathrm{~g} / 16 \mathrm{ml}$ \\
\hline 3. & $24 \mathrm{~h}$ & $1,5 \mathrm{~mol} / \mathrm{l}$ & $3 \mathrm{~g} / 30 \mathrm{ml}$ \\
\hline
\end{tabular}

\subsection{Experimental methods}

Powder X-ray diffraction profiles were collected on beamline $\mathrm{CuK}_{\alpha}$ by Siemens D-5000 diffractometer with Bragg-Brentano geometry. The scattered radiation was detected in step scan mode (step size of $0.02^{\circ}, 4 \mathrm{~s}$ counting time on $2^{\circ}-150^{\circ}$ interval) after the secondary graphite monochro- 
mator in the function of $2 \Theta$ (scattering angle) by a scintillation detector.

Secondary electron (SE) images and EDX measurements were recorded on an AMRAY 1830 scanning electron microscope equipped with EDAX PV9800 energy dispersive spectrometer.

\section{RESULTS}

\subsection{X-ray powder diffraction}

The raw material is kaolinite with some quartz and muscovite contaminations.

Heating the kaolin resulted in an X-ray amorphous metakaolinite which is the source of the $\mathrm{Si}$ and Al for LTA. Then, the sodium-hydroxide treatment produced the Linde A Type zeolite,

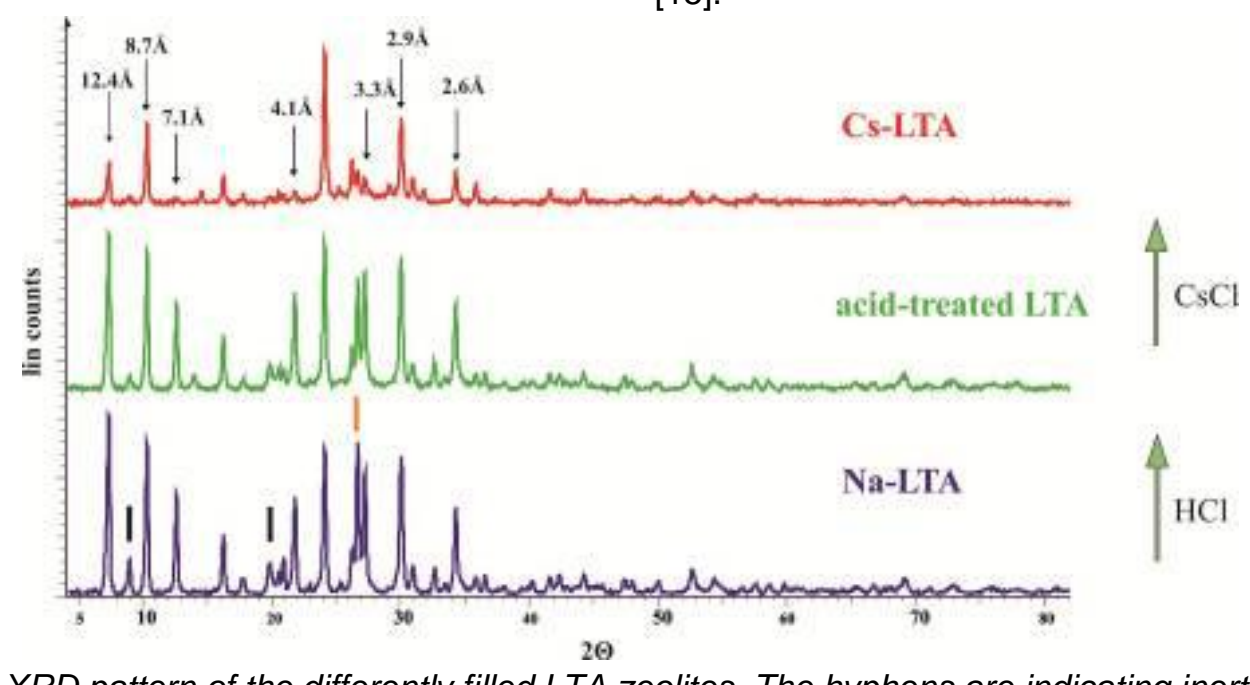

Figure 2 - XRD pattern of the differently filled LTA zeolites. The hyphens are indicating inert muscovite (black) and quartz (orange). The relative intensities of Cs-LTA peaks at the $12.4 \AA$, $8.7 \AA$, $7.1 \AA$, $4.1 \AA$, 3.3 $\AA, 2.9 \AA, 2.6 \AA$ lattice distance are weaker than those of the starting $\mathrm{Na}-L T A$.

\subsection{Scanning microscopy}

Both the raw and synthetized material appearances were examined by scanning electron microscopy. We observed the typical lamellae of kaolinite which formed $50 \mu \mathrm{m}$ aggregates. The revealed by its characteristic XRD peaks (bottom of Figure 2).

Using hydrochloric acid $\mathrm{Na}^{+}$ions were replaced by oxonium ions in the synthesied LTA zeolite that was treated for 1 day with $3 \mathrm{~mol} / \mathrm{l} \mathrm{NaOH}$. 0,124 mol $\mathrm{CsCl}$ solution was added to the 2,86 $\mathrm{g}$ sample mass using a magnetic mixer for 24 hours in room temperature. This process made changes in the XRD pattern relative intesities as show on Figure 2 . The relative intensities of Cs-LTA peaks at some lattice distance are weaker than those of the starting Na-LTA. This may result from a little structural changes. Similar changes was described in the case of natrolite exhanged with $\mathrm{Rb}$ and $\mathrm{Cs}$ [15].

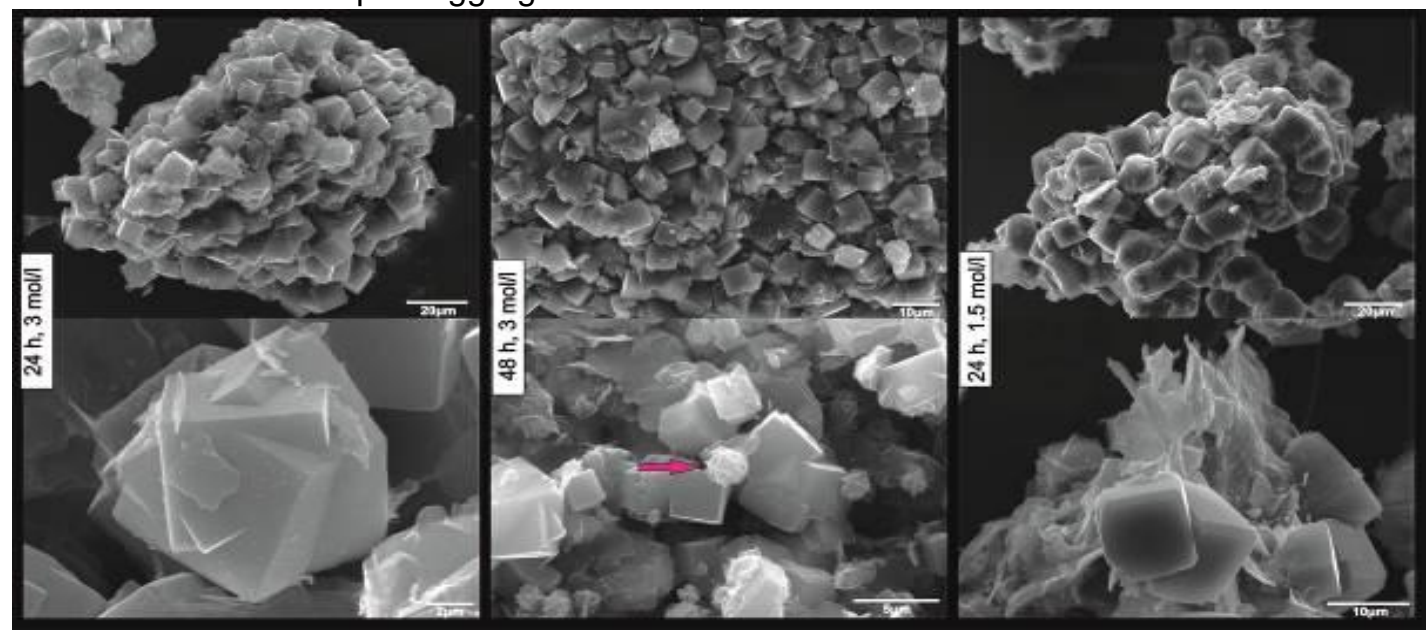

Figure 3 - Cubes and rhombdodecahedra appearance of the synthetized LTA zeolites resulted in different $\mathrm{Na}(\mathrm{OH})$-treatment. The pink arrow indicates a spherical aggregate. 
The different $\mathrm{Na}(\mathrm{OH})$-treatment resulted in different crystal sizes as shown in Table 2. The 1 day long $1.5 \mathrm{~mol} / \mathrm{l}$ case gets the biggest crystals.

Table 2 - Crystal size ranges of the synthetized LTA crystals

\begin{tabular}{|c|c|c|}
\hline \multicolumn{2}{|c|}{ Treatment } & $\begin{array}{c}\text { Edge length of the } \\
\text { crystals }\end{array}$ \\
\hline 1. & $24 \mathrm{~h}, 3 \mathrm{~mol} / \mathrm{l}$ & $8-11 \mu \mathrm{m}$ \\
\hline 2. & $48 \mathrm{~h}, 3 \mathrm{~mol} / \mathrm{l}$ & $5-8 \mu \mathrm{m}$ \\
\hline 3. & $24 \mathrm{~h}, 1.5 \mathrm{~mol} / \mathrm{l}$ & $13-14 \mu \mathrm{m}$ \\
\hline
\end{tabular}

\subsection{Crystal structures of the synthetized LTA samples}

We refined the unit cell parameters in $P m \overline{3} m$ space group using regression diagnostics with the Unit Cell program [16]. These values are shown in Table 3. As mentioned above come to be some changes in the structure when we filled the cages with Cs. It is apparent in the unit cell parameters too. This is because the higly electrostatic ion strain on the tetrahedral rings. The symmetry of the hexagonal rings changed from ditrigonal to hexagonal.

The structure determination was done using the Semi Invariant Reconstruction (SIR 2011) software. This program is solving crystal structure by Direct Methods which provides a chance to retrieve phase values through estimating structure invariants and structure seminvariants. Data can be collected with X-ray, electron or neutron sources, the required input information are the $h k l$ values and the corresponding intensities. We used X-ray powder diffraction data as input. Integration of peak area provide the intesity values for corresponding hkl, which was corrected according to multipilicity, Lorentz and polarization factors. Refinement was performed in the SHELX program package.

Table 3 - Unit cell parameters in $P m \overline{3} m$ space group refined by Unit Cell program.

\begin{tabular}{|c|c|}
\hline LTA & $a_{0}$ \\
\hline Na-LTA & $12.36180 \AA$ \\
\hline acid-treated LTA & $12.37983 \AA$ \\
\hline Cs-LTA & $12.29529 \AA$ \\
\hline
\end{tabular}

As shown on Figure 4, the construction of the typical LTA framework structure with the two kinds of cages was successful. On the left is the synthetized Na-LTA structure, where sodium ions are the blue spheres located in the a cages. In our cation exchange experiment result that $\alpha$ cages was able to tie $\mathrm{Cs}^{+}$ions too. Results are represented in Table 4 in numbers of the refined atomic positions.
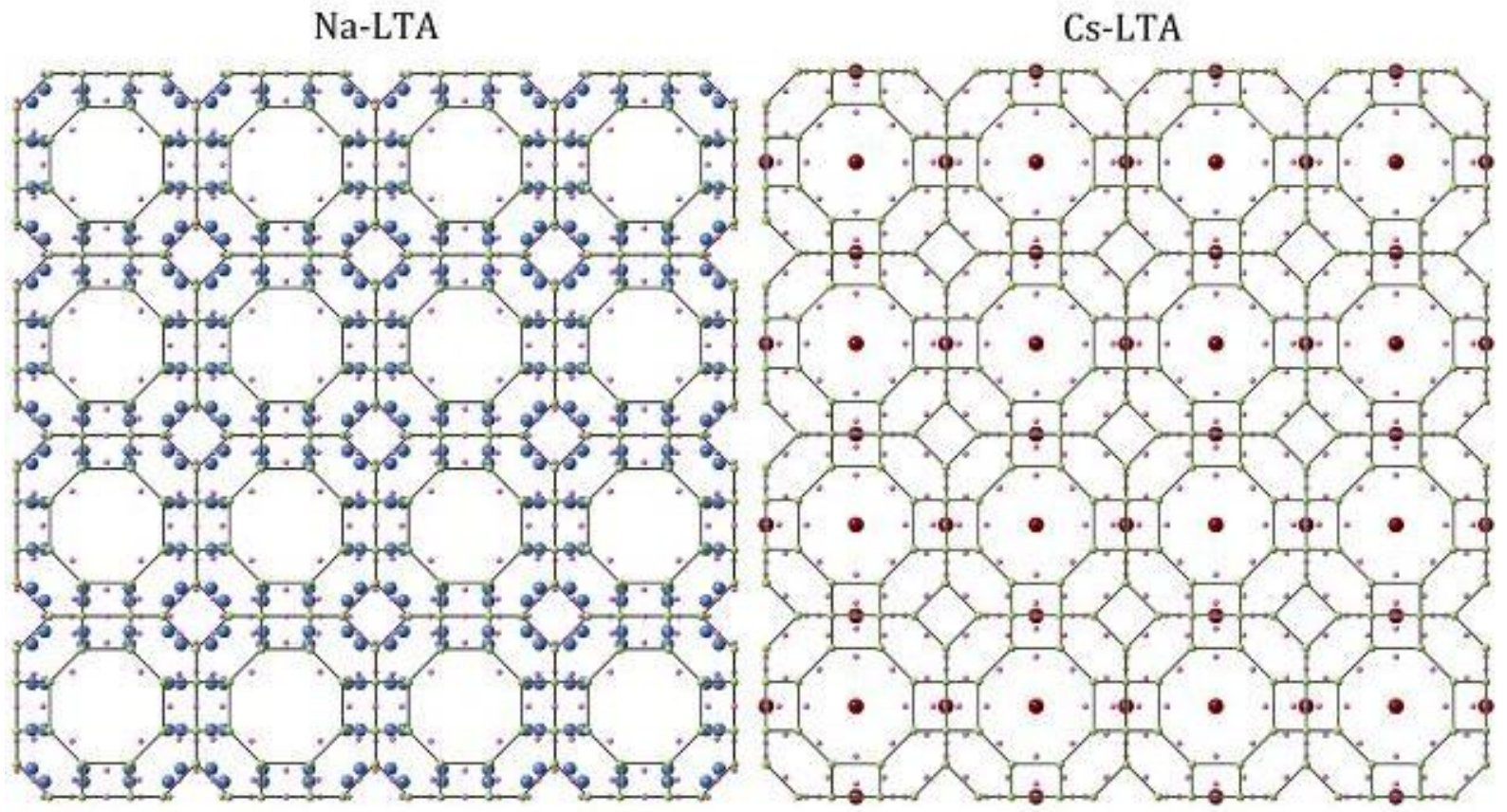

$\bullet \mathrm{Na} \bullet \mathrm{CS} \bullet \mathrm{O}$ ๑Si

Figure 4 - [001] projected crystal structures of the synthetized Na- and Cs- LTA zeolite resulted by SIR2011 followed by atomic position refinement using SHELX 
Table 4 - Refined atomic coordinates of the synthetized LTA zeolites. T and $O$ indicate the positions of the thetrahedrally coordinated Si or Al and the oxygens of tetrahedra and water, respectively; $\mathrm{Na}$ and $C$ s for sodium and cesium positions. The $x, y$, and $z$ letters indicate the atomic coordinate in 3-D, and $U$ (iso) means a thermal factor.

\begin{tabular}{|c|c|c|c|c|c|c|}
\hline LTA & Atom & $x$ & $y$ & z & Occupancy & $\mathrm{U}$ (iso) \\
\hline \multirow{5}{*}{ Na-LTA } & $\mathrm{T}$ & 0,000000 & 0,183761 & 0,364218 & 1,000000 & 0,006150 \\
\hline & O1 & 0,000000 & 0,146537 & 0,500000 & 1,000000 & 0,103530 \\
\hline & $\mathrm{O} 2$ & 0,000000 & 0,308356 & 0,308356 & 1,000000 & 0,011530 \\
\hline & $\mathrm{O} 3$ & 0,096023 & 0,096023 & 0,318898 & 1,000000 & 0,034030 \\
\hline & $\mathrm{Na}$ & 0,154760 & 0,083633 & 0,371781 & 0,717530 & 0,100140 \\
\hline \multirow{8}{*}{ acid-treated LTA } & $\overline{\mathrm{T}}$ & 0,000000 & 0,185861 & 0,365733 & 1,000000 & 0,001640 \\
\hline & 01 & 0,000000 & 0,151060 & 0,500000 & 1,000000 & 0,122210 \\
\hline & $\mathrm{O} 2$ & 0,000000 & 0,306833 & 0,306833 & 1,000000 & 0,000010 \\
\hline & $\mathrm{O} 3$ & 0,098556 & 0,098556 & 0,327788 & 1,000000 & 0,000010 \\
\hline & O4 & 0,000000 & 0,266369 & 0,371467 & 1,000000 & 0,048720 \\
\hline & O5 & 0,064781 & 0,162078 & 0,382534 & 1,000000 & 0,040230 \\
\hline & O6 & 0,000000 & 0,500000 & 0,500000 & 1,000000 & 0,011320 \\
\hline & 07 & 0,046362 & 0,500000 & 0,500000 & 1,000000 & 0,058730 \\
\hline \multirow{6}{*}{ Cs-LTA } & $\mathrm{T}$ & 0,000000 & 0,179910 & 0,364790 & 1,000000 & 0,080600 \\
\hline & O1 & 0,000000 & 0,225700 & 0,500000 & 1,000000 & 0,086900 \\
\hline & $\mathrm{O} 2$ & 0,000000 & 0,296450 & 0,296450 & 1,000000 & 0,066460 \\
\hline & $\mathrm{O} 3$ & 0,109090 & 0,109090 & 0,345210 & 1,000000 & 0,065930 \\
\hline & Cs1 & 0,000000 & 0,500000 & 0,500000 & 0,285300 & 0,000010 \\
\hline & O5 & 0,071400 & 0,500000 & 0,500000 & 0,514800 & 0,000010 \\
\hline
\end{tabular}

\section{CONCLUSIONS}

In our experiment Linde Type A zeolite crystals were produced successfully using $(\mathrm{NaOH})$ method. The synthesized LTA crystals exhibit cube and sphere shapes as shown by scanning electron microscopy. We used for cation exchange $\mathrm{Cs}^{+}$ion, a worldwide known cation after Fukushima. We noticed decrease on the XRD pattern relative intensities after cation changes.

Using SIR2011 software we reconstructed the framework of LTA zeolite from X-ray powder diffraction data sets. Linking the $\mathrm{Si}$ atoms we drew the typical structure of $\alpha$ and $\beta$ cages.

After the acidic and $\mathrm{CsCl}$ treatment the $\mathrm{Cs}^{+}$ions exchange the $\mathrm{Na}+$ ions and they were localized in the $\alpha$ cages. Due to overlapping reflections, some samples resulted in high R-factor values. However, the LTA-type framework proved to be evident. The main result of this work was the structure determination using a basic method, such as X-ray powder diffraction.

\section{Acknowledgment}

The authors gratefully thank Judit Tóthné Király and Ildikó Cora for their kind help in recording the X-ray diffraction patterns and structure determination, respectively.

\section{REFERENCES}

[1] A.F.Masters, T.Maschmeyer (2011) Zeolites - From curiosity to cornerstone, Microporous and Mesoporous Materials, 142, 423-438.

[2] R.W.Tschernich (1992) Zeolite of the world, Geosience Press Inc., USA.

[3] T.Kubota S.Fukutani, T.Ohta, Y.Mahara (2013) Removal of radioactive cesium, strontium, and iodine from natural waters using bentonite, zeolite, and activated carbon, Journal of Radioanalytical and Nuclear Chemistry, 296, 981-984.

[4] K.Y.Lee, Kw.W.Kim, M.Park, J.Kim, M.Oh, Eil-Hee Lee, D.Y.Chung, J.Kw.Moon (2016) Novel application of nanozeolite for radioactive cesium removal from high-salt wastewater, Water Research, 95, 134-141. 
[5] C.A.Ríos, C.D.Williams, M.A.Fullen (2008) Nucleation and growth history of zeolite LTA synthesized from kaolinite by two different methods, Applied Clay Science, 42, 446-454.

[6] L.Ayelea, J.Pérez-Parienteb, Y.Chebudea, I.Díaz (2016) Conventional versus alkali fusion synthesis of zeolite A from low grade kaolin, Applied Clay Science,132-133, 485-490

[7] N.E.Gordina, V.Yu.Prokof'ev, Yu.N.Kul'pina, N.V.Petuhova, S.I.Gazahova, O.E. Hmylova (2016) Effect of ultrasound on the synthesis of low-modulus zeolites from a metakaolin, Ultrasonics Sonochemistry, 33, 210-219.

[8] T.Vandermeersch, T.R.C.Van Assche, J.F.M. Denayer, W. De Malsche (2016) A continuous flow reactor setup as a tool for rapid synthesis of micron sized NaA zeolite, Microporous and Mesoporous Materials, 226, 133-139

[9] B.Saida, Th.Cacciaguerraa, F.Tancretb, F.Fajulaa, A.Galarneaua (2016) Size control of self-supported LTA zeolite nanoparticles monoliths, Microporous and Mesoporous Materials, 227, 176-190

[10] M.Gougazeh, J.-Ch.Buhl (2014) Synthesis and characterization of zeolite $\mathrm{A}$ by hydrothermal transformation of natural Jordanian kaolin, Journal of the Association of Arab Universities for Basic and Applied Sciences, 15, 35-42

[11] V.Yu.Prokof'ev, N.E.Gordina (2014) Preparation of granulated LTA and SOD zeolites from mechanically activated mixtures of metakaolin and sodium hydroxide, Applied Clay Science, 101, 4451.

[12] J.-Ch.Buhl (2016) On the autothermal synthesis of zeolites, Microporous and Mesoporous Materials, 222,73-79.

[13] Database of Zeolite structures: http://www.izastructure.org/

[14] T.Ikeda, F.Izumi, T.Kodaira, T.Kamiyama (1998) Structural Study of Sodium-Type Zeolite LTA by Combination of Rietveld and Maximum-Entropy Methods, Chem. Mater.,10 (12), 3996-4004.

[15] Y.Lee, Yo.Lee, D.Seoung (2010) Natrolite may not be a "soda-stone" anymore: Structural study of fully $\mathrm{K}-, \mathrm{Rb}-$, and Cs-exchanged natrolite, American Mineralogist, 95, 1636-1641.

[16] T.J.B. Holland, S.A.T.Redfern (1997) Unit Cell Refinement from Powder Diffraction Data: The Use of Regression Diagnostics, Mineralogical Magazine, $61,65-77$.

\section{IZVOD}

\section{SINTEZA I ISPITIVANJE STRUKTURE LTA ZEOLITA DOBIJENOG IZ KAOLINA}

Cilj ovog rada je sinteza $i$ ispitivanje kristalne strukture sodalitnog zeolita korišćenjem tehnike rendgenske difrakcije. Korišćenjem podataka dobijenih rendgenskom difrakcionom analizom uspešno je određena struktura kristalne rešetke LTA zeolita. Kako bi se pokazala upotrebljivost LTA u uklanjanju nuklearnog otpada u strukturi dobijenog uzorka urađena je jonska izmena sa $\mathrm{Cs}^{+}$ jonima.

Upotrebom metode sa $\mathrm{NaOH}$ iz metakaolinita kao početnog materijala sintetisani su kristali LTA zeolita. Skenirajućom elektronskom mikroskopijom pokazano je da su dobijeni LTA kristali kubnih $i$ sfernih oblika.

$\cup$ LTA rešetki izmenljivi katjoni ( $\mathrm{Na}^{+}$joni) izmenjeni su najpre $\mathrm{H}_{3} \mathrm{O}^{+}$a zatim $\mathrm{Cs}^{+}$jonima. Upotrebom SIR (Semi Invariant Reconstruction) softvera i korišćenjem podataka dobijenih rendgenskom spektroskopijom praćene su dobijene strukturne promene u uzorku.

Kao polazni podaci za strukturna određivanja korišćene su hkl vrednosti i intenziteti odgovarajućih spektralnih linija. Zbog preklapanja refleksija kod nekih uzoraka došlo je do pojave većih vrednosti $R$ faktora. Ipak, očigledno je da je dobijen LTA tip rešetke. Softverski paket SHELIX je korišćen za prikazivanje preraspodele atomskih pozicija.

Ključne reči: sinteza, zeolit, kaolinit, metakaolinit, LPA, jonska razmena Cs, SIR.

Naučni rad

Rad primljen: 01. 11. 2016.

Rad prihvaćen: 30. 11. 2016.

Rad je dostupan na sajtu: www.idk.org.rs/casopis 